\title{
DIGITALNO, VIRTUALNO, ONLINE - U FOKUSU
}

\section{DIGITAL, VIRTUAL, ONLINE - IN FOCUS}

\author{
Vikica Semenski \\ Knjižnice grada Zagreba \\ vikica.semenski@kgz.hr \\ Jagoda Ille \\ Knjižnice grada Zagreba \\ jagoda.ille@kgz.hr \\ Višnja Cej \\ Knjižnice grada Zagreba \\ visnja.cej@kgz.hr
}

\author{
$\mathrm{UDK} / \mathrm{UDC}$ \\ [027.022:004.738.5]:616.2- \\ 044.372:550.34(497.5 Zagreb) \\ Stručni rad / Professional paper \\ Primljeno / Received: 15. 1. 2021. \\ Prihvaćeno / Accepted: 13. 4. 2021.
}

\section{Sažetak}

Cilj. Knjižnice grada Zagreba korisnicima nude raznovrsne mrežne usluge i sadržaje, a njihova važnost dodatno je istaknuta tijekom fizičkog zatvaranja zbog pandemije bolesti COVID-19 i dodatnih poteškoća izazvanih potresom. Cilj je rada analizom usluga i sadržaja dostupnih korisnicima Knjižnica grada Zagreba tijekom zatvorenosti knjižnica te usluga i sadržaja nastalih u to vrijeme potvrditi pretpostavku o opravdanosti trajnog ulaganja u sljedeća područja: kvalitetnu mrežnu uslugu i sadržaje, nabavu elektroničke građe, edukaciju djelatnika za vještine i znanja potrebne za rad na daljinu te $u$ opremu koja podržava i rad na daljinu i povećan interes korisnika za mrežne usluge i sadržaje.

Vjesnik bibliotekara Hrvatske 64, 1(2021), 137-156

ISSN 0507-1925 
Metodologija. Korištenje pojedinih digitalnih usluga i sadržaja analizirano je kroz statističke podatke prikupljene mrežnim alatom Google Analytics, bilježenjem prenošenja i korištenja digitalnih sadržaja KGZ-a u medijima i društvu. Podaci iz 2020. godine navedeni su za razdoblja prije, tijekom i nakon završetka zatvaranja knjižnica kako bi se došlo do zaključaka o promjenama u pristupu i korištenju usluga i sadržaja u tim posebnim okolnostima. Kao dopuna navedenim podacima iz 2020. godine, za dio digitalnih sadržaja i usluga napravljena je usporedba s podacima za 2019. godinu.

Rezultati. Prikazana važnost ponude mrežnih usluga i sadržaja Knjižnica grada Zagreba (Digitalne zbirke, e-knjiga, katalog, Kalendar godišnjica, kanali društvenih medija, Pitajte knjižničare), koji bilježe značajne promjene korištenja tijekom fizičkog zatvaranja knjižnica, temelj su za određivanje prioriteta u planiranju daljnjeg razvoja Knjižnica grada Zagreba te poticaj za cjelovito sagledavanje posljedica izvanrednih događaja kako bi se učinkovito djelovalo na daljnji rad i razvoj knjižnica.

Originalnost i vrijednost. Osim što donosi prikaz jednog dijela knjižnične ponude dostupnog korisnicima u uvjetima potpunog zatvaranja velike knjižnične mreže, članak podupire pretpostavke o važnosti razvoja knjižničnih usluga i sadržaja temeljenih na informacijsko-komunikacijskim tehnologijama te važnosti trajnog ulaganja u digitalni segment knjižničnog poslovanja.

Ključne riječi: digitalizacija, mrežne knjižnične usluge, posudba $e$-knjiga, virtualne izložbe

\section{Abstract}

Purpose. The Zagreb City Libraries offer their users a variety of online services and content, the importance of which was even more strongly emphasized during the period of physical closure due to the pandemic of the COVID-19 disease and additional difficulties caused by the Zagreb earthquake. The aim of this paper is to use the analysis of the services and content available to the Zagreb City Libraries' users during the lockdown, to corroborate the premise of the importance of permanent investment in the following areas: the quality online services and content, the e-book acquisition, employee education for the skills and knowledge required for remote work from home, and in the technological equipment that supports both the remote work and the increased user access to the online services and content.

Methodology. The use of online services and content was analyzed through statistical data collected by the Google Analytics online tool and by tracking the use of digital content of the Zagreb City Libraries in public media and society. The 2020 data are provided for the periods before, during, and after libraries full closures in order to draw conclusions about changes in access to and use of online services and content. Also, as a supplement to the data from 2020, a comparison was made with the 2019 data for some of the digital contents and services. 
Findings. The importance of the Zagreb City Libraries' online services and content (Digital collections, e-books, catalog, Anniversary calendar, social media channels, Ask a Librarian service), which record significant changes in use during the period of physical closure of libraries, is the basis for the further planning of priorities in development of the Zagreb City Libraries and an incentive for a comprehensive analysis of the consequences of these exceptional events, in order to effectively influence the further operations and development of libraries.

Originality and value. In addition to presenting the only modes of the library services and content available to users during the lockdown of a large library network, the paper supports the premise of the crucial importance of the library services and content based on information and communication technologies and the importance of a continuous investment in the libraries' digital activities.

Keywords: digitization, virtual exhibitions, e-book lending, online library services

\section{Uvod}

Knjižnice grada Zagreba omogućuju pristup digitaliziranoj građi iz svojih zaštićenih zbirki na portalu Digitalne zbirke, posudbu $e$-knjiga kroz aplikaciju $Z a K i$ Book, pretraživanje knjižnične građe na mrežnom katalogu, izbor građe o značajnim događajima i osobama korištenjem usluge Kalendar godišnjica, virtualne izložbe, tematske izbore građe kroz uslugu Pitajte knjižničare, pristup snimljenim događanjima na YouTube kanalu i komunikaciju na društvenim mrežama.

Nakon što je 11. ožujka 2020. Svjetska zdravstvena organizacija proglasila globalnu pandemiju uzrokovanu koronavirusom SARS-CoV-2, u Republici Hrvatskoj 16. ožujka donesena je odluka o prestanku rada svih obrazovnih ustanova, a 18. ožujka o zatvaranju knjižnica.

Zbog štete koju je mnogim knjižnicama nanio potres koji je grad Zagreb i Zagrebačku županiju pogodio 22. ožujka, pristup fizičkoj građi bio je otežan ili onemogućen, te je do 27. travnja, kada su knjižnice ponovno otvorene za korisnike, korištenje građe bilo moguće samo kroz mrežni pristup digitalnim sadržajima.

U radu je dan prikaz digitalnih sadržaja i usluga Knjižnica grada Zagreba koje korisnicima omogućuju mrežni pristup punom sadržaju pojedinih jedinica građe, zatim prikaz usluga koje pružaju informacije o građi ili pristup videosnimkama pojedinih događanja.

Prikaz Digitalizirane zagrebačke baštine, koja je dostupna na portalu Digitalne zbirke KGZ-a uz pristup punom sadržaju digitaliziranih jedinica, navodi i statističke podatke o posjećenosti portala u 2020. godini te njihovu usporedbu s podacima 
iz 2019. Kroz pojedine primjere prikazane su mogućnosti brzog reagiranja na aktualne događaje korištenjem dostupne digitalizirane građe $u$ postavljanju virtualnih izložbi i drugih kreativnih sadržaja.

Dalje su u radu navedene osnovne informacije o posudbi $e$-knjiga, usluzi potpuno integriranoj u knjižnični sustav ZaKi koja putem mrežnog kataloga kroz aplikaciju ZaKi Book omogućuje korisnicima posudbu knjiga u formatu EPUB. Uz opis usluge, navedeni su statistički podaci za 2020. godinu te dijelom za 2019. godinu jer je pružanje te usluge započelo krajem svibnja 2019.

Nakon prikaza posudbe $e$-knjiga slijedi prikaz virtualnih izložbi koje dijelom također omogućuju pristup punom sadržaju odabrane građe te statistički podaci o njihovu korištenju.

Nadalje je naveden prikaz korištenja mrežnog kataloga i Kalendara godišnjica. Posebno je prikazano funkcioniranje usluge Pitajte knjižničare u okolnostima nedostupnosti fizičke građe.

Utjecaj pandemije i potresa na korištenje digitalnih usluga i sadržaja analiziran je kroz statističke podatke prikupljene mrežnim alatom Google Analytics.

\section{Digitalizirana zagrebačka baština}

Digitalizaciju vrijedne i rijetke građe iz zaštićenih zbirki Gradske knjižnice (Zavičajna zbirka Zagrabiensia, Zbirka rijetkih knjiga i rukopisa (Rara), Zaštićena zbirka Glazbenog odjela, Zaštićena zbirka Hrvatskog centra za dječju knjigu) Knjižnice grada Zagreba provode od 2008. godine kroz projekt Digitalizirana zagrebačka baština. ${ }^{1}$ Dio građe Knjižnice Božidara Adžije uključen je u projekt 2016. godine. Do $2019 .^{2}$ godine digitalizirano je 540 naslova raznovrsne građe, što čini oko 54000 stranica, 20000 minuta, odnosno 2,9 TB podataka. Digitalizirana građa organizirana je u zbirke: Grafička građa, Kartografska građa, Knjige, Notni zapisi, Rukopisi, Serijske publikacije, Sitni tisak, Usmeni izvori, Zvučni zapisi. Građa je okupljena i u tematskim cjelinama: Glasovi književnog petka, Ilirci, Izdanja zagrebačkih tiskara 17. i 18. stoljeća, Iz opusa Dragutina Domjanića, Iz opusa fra Bernardina Sokola, Iz opusa Franje Serafina Vilhara-Kalskog, Knjige za djecu i mladež, Priznanja zagrebačkih društava, Zagreb na pragu modernog doba, $\mathrm{Za}$ radnička prava.

\footnotetext{
1 Za prikaz Digitalizirane zagrebačke baštine u kontekstu drugih digitalizacijskih projekta vidi: Škrabo, K.; R. Vrana. Digitalne zbirke u narodnim knjižnicama u Hrvatskoj. // Vjesnik bibliotekara Hrvatske 60, 1(2017), 103-136. DOI: https://doi.org/10.30754/vbh.60.1.539. Također, za prikaz Digitalizirane zagrebačke baštine u kontekstu digitalizacijskih projekata slavenskih zemalja vidi: Nagovnak, K. Informationsressourcen für Slawisten. Berlin: De Gruyter Saur, 2017. Str. 126.

2 Građa digitalizirana tijekom 2020. godine nije uključena u ove statističke podatke jer u navedenom razdoblju još nije bila javno dostupna.
} 
Građa digitalizirana do 2015. godine dostupna je i na portalu Digitalizirana zagrebačka baština. ${ }^{3}$ Sva građa dostupna je na novom portalu Digitalne zbirke Knjižnica grada Zagreba ${ }^{4}$ od 2017. godine.

Statistički podaci navedeni u radu odnose se samo na podatke novog portala Digitalne zbirke Knjižnica grada Zagreba. Podaci su prikupljeni alatom Google Analytics. Usporedna analiza s prethodnom godinom napravljena je za razdoblje od 1. 1. do 10. 9. 2020. i za isto razdoblje u 2019. godini.

Posebno je napravljena analiza podataka za određena razdoblja tijekom 2020. koja su bila obilježena potresom i pandemijom. Budući da je trajanje promatranih razdoblja različito, analiza je napravljena prema prosječnoj dnevnoj statistici kako bi podaci bili realno usporedivi.

\subsection{Usporedba podataka o posjećenosti portala Digitalne zbirke u 2019. i 2020. godini}

U odnosu na prethodnu godinu, broj posjeta portalu Digitalne zbirke porastao je za $111 \%$, s 4578 posjetitelja u 2019. godini na 9656 posjetitelja u 2020. godini (slika 1). Broj pregleda porastao je za $65 \%$, sa 107409 pregleda u 2019. godini, na 176932 u 2020. godini. ${ }^{5}$

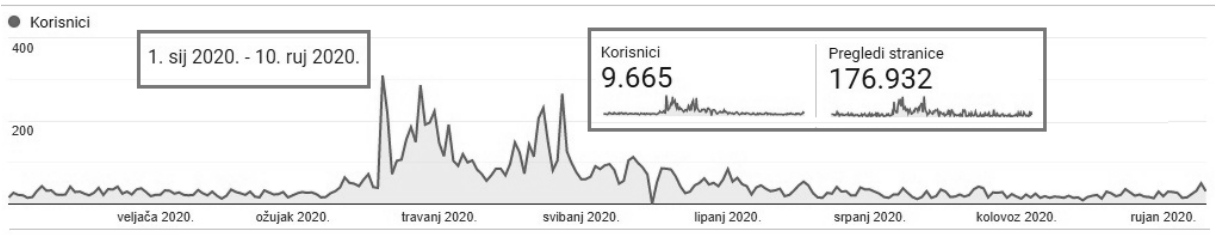

Slika 1. Grafički prikaz posjeta na portalu Digitalne zbirke KGZ-a od 1. 1. do 10. 9. 2020.

Grafički prikaz posjeta portalu pokazuje ujednačenu posjećenost tijekom 2020. godine uz izrazito povećanje od ožujka do svibnja. Osobito visoki porast posjeta portalu dogodio se nakon zatvaranja knjižnica i potresa, posebno krajem ožujka i u travnju, ali je posjećenost ostala vrlo visoka tijekom svibnja i natprosječna tijekom lipnja.

\footnotetext{
3 Digitalizirana zagrebačka baština. // Knjižnice grada Zagreba. [citirano: 2021-03-26]. Dostupno na: http://kgzdzb.arhivpro.hr.

4 Digitalizirana zagrebačka baština: zbirke. // Knjižnice grada Zagreba. [citirano: 2021-03-26]. Dostupno na: https://digitalnezbirke.kgz.hr.

5 Statistika posjeta za cijelu 2019. i 2020. godinu pokazuje još izraženiji porast posjeta portalu. Dok je od 1. 1. do 31. 12. 2019. bilo ukupno 7234 posjeta i 157123 pregleda portala, od 1. 1. do 31. 12. 2020. bilo je 15974 posjeta i 315193 pregleda, što je povećanje posjeta od $121 \%$ i pregleda od $101 \%$.
} 
Statistika posjeta za 2019. godinu, primjerice, ne pokazuje poseban rast posjeta u pojedinim mjesecima (slika 2 ).

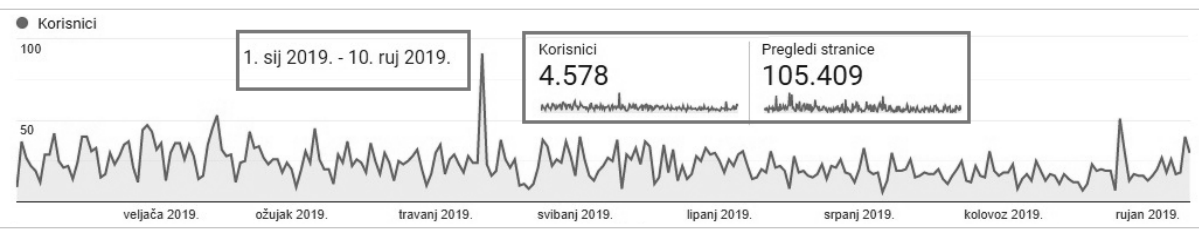

Slika 2. Grafički prikaz posjeta na portalu Digitalne zbirke KGZ-a od 1. 1. do 10. 9. 2019.

Grafički prikaz posjeta tijekom 2019. godine jasno pokazuje kontinuiranu ujednačenost bez značajnih odstupanja. Tijekom 2019. veće odstupanje od prosječne posjećenosti zabilježeno je samo jedan $\operatorname{dan}^{6}$ (četvrtak, 11. 4. 2019. - 91 posjetitelj).

\subsection{Usporedba podataka o posjećenosti portala Digitalne zbirke tije- kom 2020. godine u odnosu na razdoblje zatvorenosti knjižnica}

U analizi statističkih pokazatelja posjeta portalu od 1.1. do 10. 9. 2020. godine promatrana su četiri razdoblja: 1) - cijelo razdoblje od 254 dana za koje su prikupljeni podaci (1. 1. - 10. 9. 2020.); 2) - razdoblje od 126 dana nakon ponovnog otvaranja knjižnica (27. 4. - 10. 9. 2020.); 3) - razdoblje od 41 dana za vrijeme zatvaranja knjižnica (18. 3. - 27. 4. 2020.); 4) - razdoblje od 77 dana prije zatvaranja knjižnica (1. 1. - 17. 3. 2020.).

Tablica 1 prikazuje usporedni broj posjeta i pregleda na portalu za navedena četiri razdoblja.

Usporedba statističkih podataka napravljena je prema prosječnoj dnevnoj posjeti korisnika u navedenim razdobljima.

Posjećenost portala tijekom cijelog analiziranog razdoblja u 2020. (1. 1. 10. 9. 2020.) u odnosu na razdoblje prije zatvaranja knjižnica (1. 1. - 18. 3. 2020.) ukupno je porasla za $58 \%$. U vrijeme zatvaranja knjižnica (18. 3. - 27. 4. 2020.) izrazito je visok porast posjeta u odnosu na razdoblje prije zatvaranja knjižnica i iznosi 367 \%. Nakon ponovnog otvaranja knjižnica (27. 4. - 10. 9. 2020.) porast u odnosu na razdoblje prije zatvaranja knjižnica dijelom je zadržan i iznosi $29 \%$.

6 Do kraja 2019. godine za još dva dana zabilježena je povećana posjećenost portalu, u četvrtak 24. listopada (114 posjeta) i petak 20. prosinca (150 posjeta). 
Tablica 1. Prosječni dnevni posjeti na portalu Digitalne zbirke KGZ-a od 1. 1. do 10. 9. 2020.

\begin{tabular}{|l|r|r|r|r|}
\hline \multicolumn{2}{|l|}{ Posjeti portalu Digitalne zbirke KGZ-a } \\
\hline Razdoblje & $\begin{array}{c}\text { Ukupno } \\
\text { korisnika }\end{array}$ & $\begin{array}{c}\text { Dnevno } \\
\text { korisnika }\end{array}$ & $\begin{array}{c}\text { Ukupno } \\
\text { pregleda }\end{array}$ & $\begin{array}{c}\text { Dnevno } \\
\text { pregleda }\end{array}$ \\
\hline $\begin{array}{l}\text { Cijelo razdoblje } \\
\text { 1. 1. 2020. - 10. 9. 2020. (254 dana) }\end{array}$ & 9656 & 38 & 176932 & 697 \\
\hline $\begin{array}{l}\text { Razdoblje nakon ponovnog otvaranja } \\
\text { 27. 4. 2020. - 10. 9. 2020. (126 dana) }\end{array}$ & 3879 & 31 & 75779 & 601 \\
\hline $\begin{array}{l}\text { Razdoblje za vrijeme zatvaranja } \\
\text { 18. 3. 2020. - 27. 4. 2020. (41 dan) }\end{array}$ & 4578 & 112 & 75128 & 1832 \\
\hline $\begin{array}{l}\text { Razdoblje prije zatvaranja } \\
\text { 1. 1. - 17. 3. 2020. (77 dana) }\end{array}$ & 1849 & 24 & 30454 & 396 \\
\hline
\end{tabular}

\subsection{Ponovna uporaba Digitalizirane zagrebačke baštine}

Ponovna uporaba digitalizirane građe posebno je naglašena i podržana u mnogim zakonima, strategijama, planovima za digitalizaciju kulturne baštine i dokumentima: od Strategije e-Hrvatske, koja određuje temeljne smjernice digitalnog razvoja, osiguranja računalne infrastrukture, uspostavu sustava podrške za ponovno korištenje javnih informacija, Strateškog plana Ministarstva kulture 2018. $2020 .{ }^{8} \mathrm{~s}$ planovima digitalizacije kulturne baštine, do dokumenata lokalnih uprava i pojedinih ustanova, kao i temeljnih stručnih dokumenata, poput Manifesta za digitalne knjižnice. ${ }^{9}$ Strategija kulturnog i kreativnog razvitka Grada Zagreba 2015. - 2022. ${ }^{10}$ posebno ističe doprinos digitalno dostupnih sadržaja atraktivnosti i pre-

\footnotetext{
7 Usp. Ministarstvo uprave. Strategija e-Hrvatska 2020. 2017. [citirano 2020-12-15]. Dostupno na: https://rdd.gov.hr/UserDocsImages//MURH migracija\%20s\%20weba//Strategija_e-Hrvatska_2020.pdf.

U poglavlju Kulturna i nacionalna baština, str. 64, posebno je naglašena digitalizacija kulturne baštine i njezino korištenje u stvaranju novih proizvoda i usluga te u obrazovanju, znanosti, umjetnosti i gospodarstvu.

8 Ministarstvo kulture. Strateški plan Ministarstva kulture 2018. - 2020. Zagreb: Ministarstvo kulture, 2017.

9 IFLA/UNESCO Manifest za digitalne knjižnice. [citirano 2020-12-15]. Dostupno na: https:// www.ifla.org/files/assets/digital-libraries/documents/ifla-unesco-digital-libraries-manifesto-hr.pdf. 10 Strategija kulturnog i kreativnog razvitka Grada Zagreba 2015. - 2022. Zagreb, 2015. [citirano 2020-12-15]. Dostupno na: https://www.zagreb.hr/userdocsimages/arhiva/04\%20Strategija.pdf.
} 
poznatljivosti kulturnog sadržaja. Knjižnice grada Zagreba u Strateškom planu ${ }^{11}$ navele su razvoj digitalne knjižnice kao jedan od prioriteta te su posebno naglasile razvoj novih mrežnih usluga. Uz uvriježeni način korištenja digitalizirane građe u izradi virtualnih izložbi, ${ }^{12}$ publikacijama, ${ }^{13}$ stručnim radovima i dr., izvanredne okolnosti s kojima smo bili suočeni dodatno su potaknule pronalaženje novih načina ponovne uporabe Digitalizirane zagrebačke baštine.

Tijekom zatvorenosti knjižnica pokrenuta je izrada zabavnih mrežnih igara korištenjem digitalizirane građe. Atraktivne ilustracije dječjih knjiga i razglednice poslužile su za kreiranje mrežnih slagalica s namjerom pružanja novih igara i zabave za djecu i cijelu obitelj tijekom zatvaranja škola i ograničenog boravka na otvorenom prostoru. Pripremljene su 24 slagalice, od 30. ožujka dostupne na portalu KGZ-a, imale su 934 pregleda do 10. rujna, a značajno je povećan pregled knjiga i razglednica koje su poslužile za njihovu izradu. ${ }^{14}$

\section{Zaigrajte s nama online slagalice!}

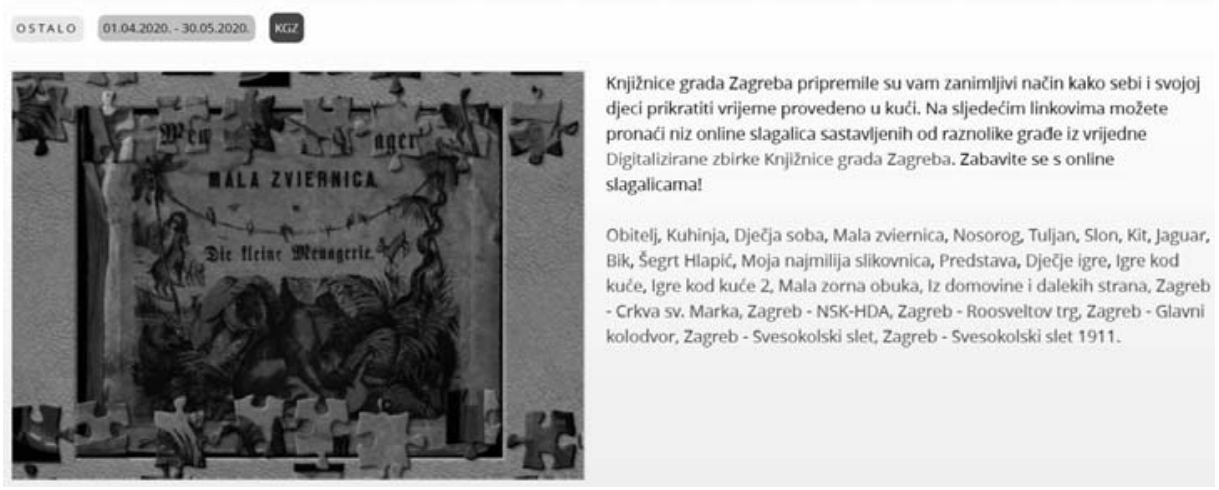

Slika 3. Izrada slagalica kao ponovna uporaba digitalizirane građe

Započet je rad na stvaranju EPUB formata za dio digitalizirane tekstovne građe kako bi se korisnicima pružile dodatne mogućnosti čitanja. Razvoj te us-

11 Bastić, D.; T. Nebesny; A. Simić-Belan. Strateški plan 2014. - 2020.: Knjižnice grada Zagreba. Zagreb: Knjižnice grada Zagreba, 2013. Str. 49.

12 Primjerice, korištenje preslike orgulja iz časopisa Glasnik Družtva za umjetnost i obrt za izložbu Hrvatska - Mađarska: 800 godina zajedničke kulturne baštine koja je zajednički projekt zajednički je projekt Mađarskog nacionalnog muzeja i Galerije Klovićevi dvori. Usp. 800 years of shared cultural heritage: Hungary-Croatia. [citirano: 2021-03-26]. Dostupno na: https://mnm. hu/virtualis/arsetvirtus/.

13 Knežević, S. Zagrebački povijesni trgovi, parkovi i neke ulice. Zagreb: ArTresor, 2020.

14 Do kraja 2020. godine Mala zvernica za zabavu i pouku mladeži, koja je poslužila za izradu više slagalica ne samo da je po prvi put je bila među deset najposjećenijih naslova na portalu nego je s 4213 pregleda ujedno bila i najpregledavaniji naslov u 2020. godini. 
luge predstavlja značajan iskorak u proširenju mrežnih sadržaja koje KGZ kreira za svoje korisnike, a time pokreće i nove mogućnosti objavljivanja građe. Izradom tog formata digitalizirana građa postaje dostupna korisnicima i u aplikaciji ZaKi Book.

Nastojanjima KGZ-a da korisnicima omogući nove načine korištenja digitalizirane građe, pridružile su se i druge ustanove. Digitalizirana građa korištena je u programu Hrvatske televizije Škola na trećem (emitiranje nastave za četiri razreda razredne nastave na 3. programu), gdje je u obradi lektire Čudnovate zgode šegrta Hlapića Ivane Brlić-Mažuranić korišteno digitalizirano izdanje KGZ-a, a preporučena je i mrežna slagalica prema naslovnici knjige. Nastavni je sat na YouTube kanalu imao 6349 pregleda do kraja kolovoza.

Digitalizirana građa korištena je za stručni i znanstveni rad, a mnoge mrežne stranice preuzimale su pojedine naslove. Potres u Zagrebu 22. 3. 2020. potaknuo je veliki interes za digitalizirane knjige Izvješće o zagrebačkom potresu 9. studenoga 1880. Josipa Torbara i Das Erdbeben von Agram im Jahre 1880. Maxa Hantkena von Prudnika, koje su digitalizirane prilikom 140. obljetnice potresa iz 1880. Dodatni interes za ta digitalizirana izdanja svakako je posljedica nedostupnosti fizičke građe, jer su u vrijeme potresa knjižnice bile zatvorene za korisnike.

\section{3. $E$-knjige}

Knjižnice grada Zagreba započele su posudbu e-knjiga 31. svibnja 2019. godine. Budući da je u potpunosti integrirana u knjižnični sustav ZaKi, od ogleda, nabave $\mathrm{i}$ obrade do posudbe $\mathrm{i}$ izrade statističkih podataka, ta je usluga jedinstvena u hrvatskim knjižnicama i predstavlja značajan iskorak ne samo za knjižnice nego i za hrvatsko izdavaštvo.

\subsection{Podaci o posudbi e-knjiga od 31. 5. 2019. do 7. 9. 2020. godine}

Kako je posudba $e$-knjiga nova usluga koju KGZ pruža svojim članovima tek od 31. svibnja 2019. godine, nije moguća usporedna analiza posudbe za odgovarajuća razdoblja u 2019. i 2020. godini. Međutim, statistika posudbe za cijelo promatrano razdoblje, od početka pružanja ta usluge u svibnju 2019. do rujna 2020. ${ }^{15}$ pokazuje izraziti porast poslije zatvaranja knjižnica, a grafički prikaz to zorno prikazuje (slika 4) - nakon početnog velikog interesa korisnika za novu uslugu, vidljiv je pad interesa i kontinuitet prosječne posudbe koji traje sve do zatvaranja knjižnica, nakon čega se posudba naglo i značajno povećava.

15 Zbog organizacijskih uvjeta statistika je dana do 7. 9. 2020. 


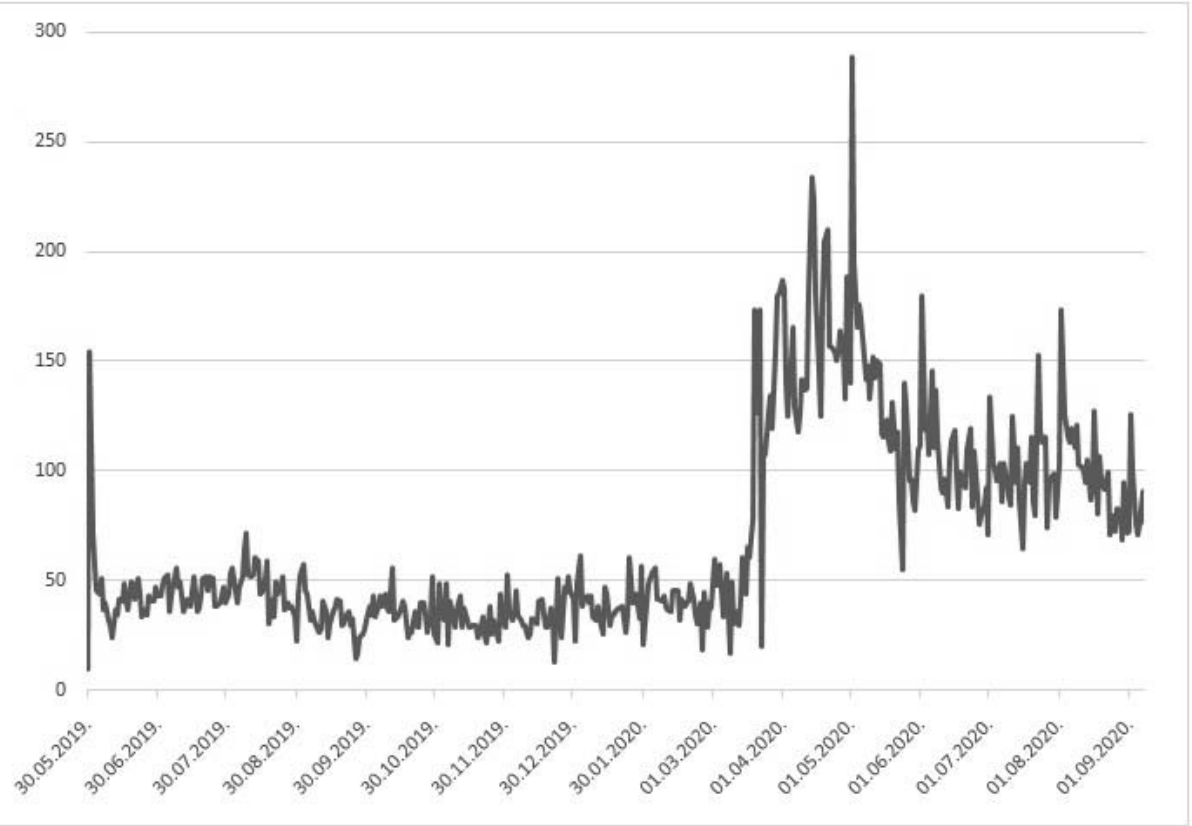

Slika 4. Grafički prikaz posudbe e-knjiga od 31. 5. 2019. do 7. 9. 2020.

Grafički prikaz posudbe $e$-knjiga zorno pokazuje razdoblja prosječnog i povećanog zanimanja korisnika za tu građu. Korisnici su bili vrlo zainteresirani za uslugu kada je pokrenuta te je na sam dan promocije, 31. 5. 2019., posuđeno više od 150 naslova, ali je nakon toga taj interes smanjen. Na slici 4 vidljiv je daljnji kontinuitet ujednačenog interesa za posudbu $e$-knjiga koji je od lipnja 2019. do ožujka 2020. bio manji od 50 posudbi dnevno. Međutim, grafikon pokazuje naglo povećanje posudbe $e$-knjiga krajem ožujka, nakon zatvaranja knjižnica. Povećani interes jasno je vidljiv do kraja promatranog razdoblja, 7. 9. 2020. u kojem je posudba uvijek bila iznad 50 naslova dnevno. Pri tome je potrebno istaknuti da grafikon pokazuje izrazitu raznolikost dnevne posudbe $e$-knjiga nakon zatvaranja knjižnica, ali se ona najčešće kretala oko 100 posudbi dnevno. Najviše posudbi (289) zabilježeno je 1. 5. 2020.

Usporedba podataka posudbe na dan zatvaranja knjižnica i potresa s posudbom na dan poslije tih događaja, zanimljiva je kao svojevrsni pokazatelj ponašanja korisnika u posebnim okolnostima. Na dan zatvaranja knjižnica 18. 3. 2020. posuđeno je 78 naslova, a već idući dan, 19. 3. 2020. posuđeno je i više nego dvostruko - 174 naslova. Vrijedi zabilježiti i ponašanje korisnika vezano uz potres: na dan potresa (22. 3. 2020.) posuđeno samo 20 naslova, a dan poslije (23. 3. 2020.) posuđeno je 107 naslova, odnosno pet puta više. 


\subsection{Usporedba podataka o posudbi e-knjiga u 2020. godini u odnosu na razdoblje zatvorenosti knjižnica}

Podaci o posudbi $e$-knjiga u vrijeme zatvorenosti knjižnica zorno pokazuju ponašanje korisnika u uvjetima nedostupnosti fizičke građe.

Tablica 2 daje pregled statistike posudbe $e$-knjiga za pojedina razdoblja od početka usluge 31. 5. 2019. do 7.9. 2020.

Od početka posudbe e-knjiga 31. 5. 2019. do zatvaranja knjižnica 18. 3. 2020., prosječna dnevna posudba bila je 40 naslova. Od 31. 5. 2019. do 7. 9. 2020. posudba je bila prosječno 70 naslova dnevno, odnosno $75 \%$ više nego do zatvaranja knjižnica. Tijekom zatvaranja knjižnica od 18.3. do 27.4.2020. posudba je narasla na prosječno 152 naslova dnevno, što je porast od $280 \%$ u odnosu na razdoblje prije zatvaranja knjižnica. Porast posudbe $e$-knjiga nastavljen je i nakon ponovnog otvaranja knjižnica 27. 4. 2020. te je do 7. 9. 2020. iznosio prosječno $110 \mathrm{knjiga}$ dnevno, a to je porast od $175 \%$ u odnosu na razdoblje prije zatvaranja knjižnica.

Ti podaci jasno pokazuju da su zatvaranje knjižnica i nemogućnost korištenja fizičke građe izazvali povećan interes korisnika za $e$-knjigom te da je taj interes u odnosu na razdoblje prije zatvaranja ostao značajno povećan nakon ponovnog otvaranja knjižnica i dostupnosti fizičke građe.

Tablica 2. Prosječna dnevna posudba e-knjiga od 31. 5. 2019. do 1. 9. 2020.

\begin{tabular}{|c|c|c|}
\hline \multicolumn{3}{|l|}{ Posudba $e$-knjiga } \\
\hline Razdoblje & $\begin{array}{l}\text { Ukupno } \\
\text { posudbi }\end{array}$ & $\begin{array}{l}\text { Dnevno } \\
\text { posudbi }\end{array}$ \\
\hline $\begin{array}{l}\text { Od početka usluge posudbe } e \text {-knjiga do zatvaranja } \\
\text { 31. 5. 2019. - 18. 3. 2020. (295 dana) }\end{array}$ & 11750 & 40 \\
\hline $\begin{array}{l}\text { Cijelo razdoblje } \\
\text { 31. 5. 2019. - 7. 9. 2020. (468 dana) }\end{array}$ & 32432 & 70 \\
\hline $\begin{array}{l}\text { Tijekom zatvaranja } \\
\text { 18. 3. 2020. - 27. 4. 2020. (41 dan) }\end{array}$ & 6226 & 152 \\
\hline $\begin{array}{l}\text { Nakon ponovnog otvaranja } \\
\text { 27. 4. 2020. - 7.9.2020. (132 dana) }\end{array}$ & 14537 & 110 \\
\hline $\begin{array}{l}\text { Kontinuirano razdoblje od } 113 \text { dana s više od } 100 \\
\text { posudbi dnevno, 19. 3. 2020. - 21. 5. } 2020 .\end{array}$ & 9898 & 150 \\
\hline
\end{tabular}




\subsection{Usporedba podataka o posudbi e-knjiga u odnosu na posudbu fi- zičke građe}

Ukupni podaci posudbe građe, u koje je uključena i posudba $e$-knjiga, dostupni su u godišnjim izvještajima Knjižnica grada Zagreba. ${ }^{16}$ U 2019. godini posuđeno je 2658754 jedinica građe, a u 2020. godini 2203967 jedinica. Premda je u 2020. godini došlo do pada posudbe od $17 \%$ u odnosu na prethodnu godinu, to se nije odrazilo na posudbu $e$-knjiga, koja je zabilježila značajan rast u odnosu na početno razdoblje pružanja usluge u 2019. godini. Razdoblje zatvaranja knjižnica uzrokovalo je pad posudbe fizičke građe, koji se nakon ponovnog otvaranja nije uspio nadoknaditi. Trend posudbe $e$-knjiga pokazuje suprotan smjer: zatvaranje knjižnica potaknulo je korisnike na posuđivanje građe koja im je mrežno dostupna, a nakon ponovnog otvaranja knjižnica ta posudba ostala je i dalje povećana.

Cjelovita analiza interesa korisnika za posudbu e-knjiga bit će moguća tek nakon 2021. godine, kada će se moći usporediti puni dvogodišnji podaci.

\section{Virtualne izložbe}

Na portalu KGZ-a, na stranici Virtualne izložbe, postavljeno je 17 izložbi, 34 izložbe postavljene su na mrežnoj stranici Zavičajne zbirke Zagrabiensia - Male izložbe te 3 izložbe na portalu Digitalne zbirke. Zbog mogućnosti brzog reagiranja, posebno su značajne upravo Male izložbe, u okviru kojih je, odmah nakon potresa, postavljena izložba Prvostolna crkva zagrebačka poslije potresa 9. studenoga 1880. - 22. ožujka 2020. ${ }^{17}$ za koju je korištena dostupna digitalizirana građa. Kako bi građa bila vidljivija i dostupna širem krugu korisnika, dio izložbi postavljen je i na portalu Virtualne izložbe NSK-a.

Za izradu raznovrsnih virtualnih izložbi kojima su knjižnice obilježile svoje aktivnosti u vrijeme pandemije i potresa, poput izložbi posvećenih kućnim knjižnicama Kućne riznice - zbirka fotografija kućnih knjižnica ${ }^{18}$, korišten je Google Photos alat za postavljanje građe na internet i povezivanje s mrežnima stranicama knjižnice.

\footnotetext{
16 Izvještaji o radu (Knjižnice grada Zagreba). [citirano: 2021-04-13]. Dostupno na: http://www. $\mathrm{kgz} . \mathrm{hr} / \mathrm{hr} / \mathrm{o}-\mathrm{nama} /$ godisnji-izvjestaji/43616.

Izvještaji donose podatke za razdoblja od 1. 1. - 31. 12. 2019. i 1. 1. - 31. 12. 2020.

17 Usp. Zbirka Zagrabiensia. // Knjižnice grada Zagreba. [citirano: 2021-03-26]. Dostupno na: http://www.kgz.hr/hr/knjiznice/gradska-knjiznica-zbirka-zagrabiensia/male-izlozbe/prvostolna-crkva-zagrebacka-poslije-potresa-9-studenoga-1880-22-ozujka-2020/55651.

18 Kućne riznice: zbirka fotografija kućnih knjižnica. // Knjižnice grada Zagreba. [citirano: 2021-03-26]. Dostupno na: http://www.kgz.hr/hr/dogadjanja/kucne-riznice-zbirka-fotografija-kucnih-knjiznica/55780.
} 


\subsection{Posjećenosti virtualnih izloz̆bi u 2019. i 2020. godini}

Virtualne izložbe zabilježile su 485 pregleda od 1.1.2019. do 10.9.2019., a 1452 pregleda u istom razdoblju 2020. godine, pri čemu je više od pola pregleda (857) bilo u razdoblju zatvaranja knjižnica (18.3.-27.4.2020.). Posjećenost Malih izložbi može se pratiti posredno kroz statističke podatke zbirke Zagrabiensia, koja je u navedenom razdoblju 2019. godine imala 686 pregleda, a 2020. godine broj pregleda je povećan na 782.Većina pregleda (426) zabilježena je također tijekom zatvaranja knjižnica.

\subsection{Posjećenosti virtualnih izloz̆bi u odnosu na ukupnu posjećenost portala KGZ-a}

Valja naglasiti da je ukupna posjećenost portala KGZ-a od 1. 1. 2020. do 31. 8. 2020., s 320294 posjeta i 1788648 pregleda, smanjena u odnosu na isto razdoblje u 2019. godini, kada je bilo 706799 posjeta i 4433971 pregled. Usprkos tome, posjećenost virtualnih izložbi porasla je u 2020. godini, što svakako ukazuje na njihovu važnost za korisnike tijekom zatvaranja knjižnica. Značajan je podatak da je uz smanjenu ukupnu posjećenost portala KGZ-a u cijelom promatranom razdoblju 2020. u odnosu na 2019. posjećenost portala ipak povećana za vrijeme zatvaranja knjižnica. Od 18. 3. 2020. do 27. 4. 2020. portal je imao 83529 posjeta i 341940 pregleda, što je značajno više nego u istom razdoblju 2019. godine, kada je bilo 59370 posjeta i 313111 pregleda.

Izložba Kućne riznice postavljena je tijekom zatvorenosti knjižnica kada je posjećena 119 puta, a do 10.9. 2020. posjećena je ukupno 139 puta.

Posjećenost virtualnih izložbi na portalu Digitalne zbirke Knjižnica grada Zagreba prati se posredno, kroz ukupnu statistiku posjećenosti portala, koja je navedena u poglavlju Digitalizirana zagrebačka baština.

\section{Mrežni katalog}

Posljedice zatvaranja knjižnica i nedostupnosti fizičke građe jasno su vidljive u korištenju mrežnog kataloga koji pruža informacije upravo o građi koja je korisnicima postala nedostupna.

Budući da se korištenje kataloga analizira upravo u kontekstu nemogućnosti posudbe fizičke građe, podaci o pretraživanju kataloga navedeni su i analizirani samo u odnosu na razdoblje zatvorenosti knjižnica u 2020. godini. 
Tablica 3 navodi statistiku pretraživanja kataloga za razdoblje od 1. 1. 2020. do 31. 8. 2020. ${ }^{19} \mathrm{U}$ tom razdoblju katalog je imao 588513 korisnika, odnosno prosječno 2412 korisnika dnevno. Do zatvaranja knjižnica (1. 1. - 18. 3. 2020.) bilo je 217504 korisnika (2 412 dnevno), a u vrijeme zatvaranja (18. 3. - 27. 4. 2020.) bilo je 122866 korisnika (2 997 dnevno).

Posjet korisnika mrežnom katalogu u cijelom promatranom razdoblju smanjen je za $18 \%$ u odnosu na razdoblje prije zatvaranja knjižnica. Potrebno je napomenuti da je za vrijeme zatvaranja knjižnica zabilježen manji porast posjeta $(4 \%) \mathrm{u}$ odnosu na razdoblje prije zatvaranja. Međutim, značajniji pad posjeta mrežnom katalogu dogodio se nakon ponovnog otvaranja knjižnica, kada je bilo 248213 posjeta (1 970 dnevno), što je $43 \%$ manje nego prije zatvaranja. Uzroci tog pada posjeta nisu posebno analizirani, ali jedan su od mogućih i uobičajenih razloga ljetni mjeseci kada je rok posudbe građe znatno produžen, a mnogi članovi KGZ-a duže borave izvan Zagreba.

Tablica 3. Pretraživanje mrežnog kataloga od 1. 1. 2020. do 31. 8. 2020.

\begin{tabular}{|l|r|r|r|r|}
\hline \multicolumn{1}{|l|}{ Pretraga mrežnog kataloga KGZ-a } \\
\hline Razdoblje & $\begin{array}{c}\text { Ukupno } \\
\text { korisnika }\end{array}$ & $\begin{array}{c}\text { Dnevno } \\
\text { korisnika }\end{array}$ & $\begin{array}{c}\text { Ukupno } \\
\text { pregleda }\end{array}$ & $\begin{array}{c}\text { Dnevno } \\
\text { pregleda }\end{array}$ \\
\hline $\begin{array}{l}\text { Cijelo razdoblje } \\
\text { 1. 1. -31. 8. 2020. (244 dana) }\end{array}$ & 588513 & 2412 & 7204504 & 29527 \\
\hline $\begin{array}{l}\text { Prije zatvaranja } \\
\text { 1. 1. - 18. 3. 2020. (77 dana) }\end{array}$ & 217504 & 2825 & 2822336 & 36654 \\
\hline $\begin{array}{l}\text { Tijekom zatvaranja } \\
\text { 18. 3. 2020. - 27. 4. 2020. (41 dan) }\end{array}$ & 122866 & 2997 & 664763 & 16214 \\
\hline $\begin{array}{l}\text { Nakon ponovnog otvaranja } \\
\text { 27. 4. 2020.-31. 8. 2020. (126 dana) }\end{array}$ & 248213 & 1970 & 3717400 & 29503 \\
\hline
\end{tabular}

\section{Kalendar godišnjica}

Kalendar godišnjica baza je podataka na portalu KGZ-a koja pruža osnovne informacije o značajnim osobama i događajima iz hrvatske i svjetske povijesti. Međutim ne sadrži pristup cjelovitim dokumentima, već samo poveznice na mrežni katalog.

Statistika pretraživanja Kalendara navedena je za razdoblje od 1. 1. 2020. do 31. 8. 2020. i dana je posredno, kroz statistiku posjećenosti portala KGZ-a.

19 Završetak prikupljanja statističkih podataka s 31.8.2020. uvjetovan je organizacijskim mogućnostima i rokom predaje izlaganja za 45. skupštinu Hrvatskog knjižničarskog društva na kojoj su podaci predstavljeni. 
Tablica 4 prikazuje ukupnu i prosječnu dnevnu posjećenost portala tijekom promatranih razdoblja. Posjećenost portalu tijekom zatvaranja knjižnica bila je $11 \%$ viša u odnosu na razdoblje prije zatvaranja, a usporedba podataka za razdoblje zatvaranja knjižnica s istim razdobljem 2019. godine pokazuje $10 \%$ više posjeta tijekom zatvaranja. Ukupno povećanje posjeta portalu KGZ-a upućuje na pretpostavku da je toliko porasla i posjećenost Kalendara godišnjica.

Tablica 4. Pretraživanje portala KGZ-a od 1. 1. do 31. 8. 2020.

\begin{tabular}{|l|r|r|r|r|}
\hline Statistika posjeta portalu KGZ-a & \multicolumn{1}{|c|}{} \\
\hline Razdoblje & $\begin{array}{c}\text { Ukupno } \\
\text { korisnika }\end{array}$ & $\begin{array}{c}\text { Dnevno } \\
\text { korisnika }\end{array}$ & $\begin{array}{c}\text { Ukupno } \\
\text { pregleda }\end{array}$ & $\begin{array}{c}\text { Dnevno } \\
\text { pregleda }\end{array}$ \\
\hline $\begin{array}{l}\text { Cijelo razdoblje } \\
\text { 1. 1. 2020. - 31. 8. 2020. (244 dana) }\end{array}$ & 320294 & 1313 & 1788648 & 7331 \\
\hline $\begin{array}{l}\text { Prije zatvaranja } \\
\text { 1. 1. - 18. 3. 2020. (77 dana) }\end{array}$ & 111009 & 1442 & 572593 & 7436 \\
\hline $\begin{array}{l}\text { Tijekom zatvaranja } \\
\text { 18. 3. 2020. - 27. 4. 2020. (41 dan) }\end{array}$ & 83529 & 2037 & 341940 & 8340 \\
\hline $\begin{array}{l}\text { Posjet portalu 2019. godine } \\
\text { 18. 3. 2019. - 27. 4. 2019. (41 dan) }\end{array}$ & 59370 & 1448 & 313111 & 7637 \\
\hline
\end{tabular}

\section{Događanja, predstave, priče, Noć knjige}

Mrežna stranica objava video materijala putem YouTube kanala KGZ-a uključivala je lutkarske predstave, čitanja slikovnica, razgovore s književnicima. Samo u okviru manifestacije Noć knjige realizirano je više od 50 događanja u Knjižnicama grada Zagreba. Najgledanija videosnimka snimljena u vrijeme zatvaranja knjižnica bilo je čitanje priče Moj tata se smanjuje Eme Pongrašić s 2267 pregleda do kraja kolovoza ${ }^{20}$.

Tablica 5 daje statistiku pregleda videozapisa raznih događanja u knjižnicama od 1. 1. 2020. do 31. 8. 2020. Pregled videozapisa na YouTube kanalu KGZ-a povećan je za $198 \%$ tijekom zatvaranja knjižnica od 18. 3. do 27. 4. 2020. u odnosu na razdoblje od početka godine do zatvaranja (1. 1. - 18. 3. 2020.). Broj pregleda od početka godine do 31. 8. 2020. neznatno je smanjen (5 \%) u odnosu na razdoblje do zatvaranja knjižnica (1. 1. - 18. 3. 2020.). Pregledi videozapisa smanjeni su više od tri puta nakon ponovnog otvaranja knjižnica. Za ovaj rad nisu posebno istraženi razlozi pada interesa za videozapise nakon ponovnog otvaranja knjižnica.

20 Ukupno je najgledanija snimka putopisno predavanje Vedrana Bađuna održano u kupoli Gradske knjižnice 5. ožujka 2019. koje do kraja kolovoza imalo 51463 pregleda. 
Tablica 5. Statistika pregleda YouTube kanala KGZ-a od 1. 1. do 31. 8. 2020.

\begin{tabular}{|l|c|c|}
\hline \multicolumn{3}{|l|}{ Pregled videozapisa na YouTube kanalu KGZ-a } \\
\hline Razdoblje & Ukupno pregleda & Dnevno pregleda \\
\hline $\begin{array}{l}\text { Cijelo razdoblje } \\
\text { 1. 1. }- \text { 31. 8. 2020. (244 dana) }\end{array}$ & 63075 & 259 \\
\hline $\begin{array}{l}\text { Prije zatvaranja } \\
\text { 1. 1. }- \text { 17. 3. 2020. (77 dana) }\end{array}$ & 20838 & 271 \\
\hline $\begin{array}{l}\text { Tijekom zatvaranja } \\
\text { 18. 3. }- \text { 27. 4. 2020. (41 dan) }\end{array}$ & 32972 & 804 \\
\hline $\begin{array}{l}\text { Nakon ponovnog otvaranja } \\
\text { 27. 4. 2020.- } 31.8 .2020 .(126 \text { dana) }\end{array}$ & 9265 & 74 \\
\hline
\end{tabular}

\section{Pitajte knjižničare}

Projekt Pitajte knjižničare ${ }^{21}$ već 16 godina pruža mrežne referentne usluge. Do rujna 2020. godine u projekt je bilo uključeno 19 narodnih knjižnica i 182 diplomirana knjižničara. Odgovoreno je na više od 110000 upita, a odgovori su javno dostupni i pretraživi. Baza poveznica organizirana je u 295 kategorija i sadrži 1 428 poveznica. Više od pola informatora, kao i odgovora na upite, dolazi iz Knjižnica grada Zagreba kao najveće knjižnične mreže u Hrvatskoj.

Kao priprema za rad u uvjetima pandemije, ravnatelji i djelatnici knjižnica koje sudjeluju u radu sustava Pitajte knjižničare zamoljeni su 16. ožujka za povratne informacije, na temelju kojih je donesena odluka o nastavljanju pružanja te usluge, unatoč otvorenim pitanjima poput osiguravanja uvjeta za rad od kuće te očekivanog pada broja upita uslijed zatvaranja obrazovnih ustanova.

U uvjetima zatvaranja knjižnica od 18. 3. do 27. 4. 2020. aktivno je bilo 45 informatora koji su odgovorili na 848 pitanja demonstrirajući svoju profesionalnu etiku te doprinoseći ugledu narodnih knjižnica. Od 32 informatora koji su odgovorili na interni upit o uvjetima pristupa sustavu, samo je dvoje radilo na službenim laptopima, ostali na privatnim računalima, a samo jedan nije koristio privatni pristup internetu.

${ }^{21}$ Usluga Pitajte knjižničare iscrpno je prikazana u člancima B. Bosančića: Usp. Bosančić, B. Online referentne usluge: pregled razvoja u teoriji i praksi. // Vjesnik bibliotekara Hrvatske 53, 1(2010), 64-86. [citirano: 2020-12-15]. Dostupno na: https://www.hkdrustvo.hr/vjesnik-bibliotekara-hrvatske/index.php/vbh/article/view/446/441; također, Bosančić, B. Put k povezivanju: usluga Pitajte knjižnčare na mrežnim stranicama narodnih knjižnica. // Vjesnik bibliotekara Hrvatske 46, 3/4(2003), 80-92. 
Kao ključni dio usluge Pitajte knjižničare u uvjetima zatvorenosti knjižnica prepoznata je educiranost djelatnika koji rade na pružanju usluge za pretraživanje kvalitetnih, javno dostupnih izvora informacija na internetu.

Podaci o pristupu stranicama Pitajte knjižničare navedeni su samo za razdoblje zatvorenosti knjižnica i uspoređeni s istim razdobljem u 2019. godini. Budući da je interes za tu uslugu kontinuiran i usklađen s uobičajenim školskim kalendarom izrade seminara, referata i drugih radova, dovoljno je usporediti navedena razdoblja kako bi se pokazao utjecaj zatvorenosti knjižnica na korištenje te usluge.

Tablica 6 daje usporedni pregled pristupa stranicama Pitajte knjižničare za vrijeme zatvaranja knjižnica od 18. 3. 2020. do 27. 4. 2020. i u istom razdoblju 2019. godine. Broj posjeta u vrijeme zatvaranja knjižnica porastao je $38 \%$, broj pojedinačnih posjetitelja $48 \%$, a broj pregleda stranica $15 \%$.

Tablica 6. Usporedni pregled pristupa stranicama Pitajte knjižničare

\begin{tabular}{|l|r|r|r|}
\hline Pregled pristupa stranicama Pitajte knjižničare \\
\hline Razdoblje & \multicolumn{1}{l|}{ Posjeti } & Posjetitelji & Stranice \\
\hline $\begin{array}{l}\text { Usporedno razdoblje u 2019. } \\
\text { 18.3.2019. - 27.4. 2019. }\end{array}$ & 20149 & 13956 & 83059 \\
\hline $\begin{array}{l}\text { Razdoblje u vrijeme zatvaranja 2020. } \\
\text { 18.3.2020. - 27.4. 2020. }\end{array}$ & 27787 & 20601 & 95385 \\
\hline
\end{tabular}

U svjetlu gore navedenih podataka o porastu pristupa mrežnom mjestu usluge Pitajte knjižničare, potrebno je naglasiti važnost sigurnog i robusnog sustava kojemu se može pristupati s bilo kojeg računala ili mobilnog uređaja, a koji od početka rada usluge razvija i održava autor i webmaster Boris Badurina.

\section{Rasprava}

Prikaz digitalnih usluga i sadržaja Knjižnica grada Zagreba naveden je u kontekstu povećanog interesa korisnika uzrokovanog izvanrednim okolnostima pandemije i potresa 2020. godine. Utjecaj tih događaja na korištenje digitalnih usluga i sadržaja prikazan je kroz statističke podatke o posjećenosti pojedinim portalima i stranicama KGZ-a. Zbog posebnih organizacijskih okolnosti i roka predaje izlaganja za 45. skupštinu Hrvatskog knjižničarskog društva na kojoj su podaci prezentirani, završni datum prikupljanja podataka nije isti za sve analizirane sadržaje i usluge.

Podaci koji se odnose na Digitaliziranu zagrebačku baštinu navedeni su za razdoblje od 1. 1. 2020. do 10. 9. 2020. i za isto razdoblje u 2019. godini te posebno 
za razdoblje prije (1. 1. - 18. 3. 2020), tijekom zatvaranja (18. 3. - 27. 4. 2020.) i nakon ponovnog otvaranja knjižnica (27. 4. - 10. 9. 2020.). Posjećenost portalu porasla je u odnosu na 2019. godinu $111 \%$, a posebno je značajan porast posjeta od $367 \%$ tijekom zatvaranja knjižnica u odnosu na razdoblje prije zatvaranja.

Statistika posudba $e$-knjiga, kao nove usluge koju KGZ pruža svojim članovima od 31. 5. 2019. godine, dana je za razdoblje 31. 5. 2019. do 7. 9. 2020. Tijekom zatvaranja knjižnica posudba $e$-knjiga porasla je $280 \%$ u odnosu na razdoblje prije zatvaranja, a nakon ponovnog otvaranja knjižnica taj porast ostao je vrlo značajan, odnosno $175 \%$ u odnosu na razdoblje prije zatvaranja.

Posjet je virtualnim izložbama dijelom iskazan kroz ukupnu posjećenost portala i stranica na kojima su izložbe postavljene. Podaci su navedeni za razdoblje 1. 1. do 31. 8. 2020. i za isto razdoblje u 2019. godini.

Važno je napomenuti da je usprkos smanjenoj posjećenosti portala u 2020. u odnosu na 2019., posjet virtualnim izložbama u 2020. godini povećan.

Podaci posjeta mrežnom katalogu navedeni su za razdoblje 1. 1. - 31. 8. 2020. i posebno za razdoblja prije i tijekom zatvaranja te nakon ponovnog otvaranja knjižnica. Premda je tijekom zatvaranja knjižnica broj posjeta katalogu neznatno povećan, vidljiv je smanjen broj posjeta nakon ponovnog otvaranja knjižnica, a razloge tome treba dodatno istražiti.

Statistiku posjete stranici Kalendar godišnjica moguće je navesti samo posredno kroz ukupnu posjećenost portala KGZ-a koja je vrijeme zatvaranja knjižnica bila je $11 \%$ veća u odnosu na razdoblje prije zatvaranja.

Video materijali raznovrsnih događanja u KGZ-u koji su objavljeni na YouTube kanalu imali su povećanu posjećenost tijekom zatvaranja knjižnica, $198 \%$ u odnosu na razdoblje prije zatvaranja, ali je nakon ponovnog otvaranja knjižnica posjećenost znatno smanjena. Podaci su navedeni za razdoblje 1. 1.-31. 8. 2020. godine.

Podaci o pristupu stranicama Pitajte knjižničare, dani za razdoblje zatvorenosti knjižnica i uspoređeni s istim razdobljem u 2019. godini, pokazuju povećanje posjeta od $38 \%$ tijekom zatvaranja knjižnica. Ostala razdoblja nisu posebno analizirana jer navedeni podaci dovoljno ukazuju na povećani interes korisnika za tu uslugu u navedenom razdoblju.

\section{Zaključak}

Uloge narodnih knjižnica kao mjesta pristupa znanju i informacijama, sigurnog mjesta za provođenje slobodnog vremena i cjeloživotno učenje te mjesta potpore obrazovanju i kulturnom životu zajednice naglo su poremećene pandemijom koronavirusa, a u Zagrebu i Zagrebačkoj županiji i razornim potresom 22. ožujka 2020. godine. 
U reagiranju na krizne događaje i kontinuirane potrebe korisnika, hrvatske narodne knjižnice iskazale si se od početaka hrvatske samostalnosti te ih ni ova izvanredna događanja u proljeće 2020. godine nisu u potpunosti omela u ostvarivanju temeljnih zadataka.

Kroz analizu usluga i sadržaja dostupnih korisnicima Knjižnica grada Zagreba tijekom zatvorenosti knjižnica te usluga i sadržaja nastalih tijekom zatvorenosti, došlo se do nekoliko važnih zaključaka.

Statistički podaci za vrijeme zatvorenosti zbog pandemije i potresa u ožujku 2020. godine pokazuju nedvojbeno povećan interes korisnika za mrežne usluge i sadržaje koje nude Knjižnice grada Zagreba.

Korištenje mrežnih usluga i sadržaja povezanih s fizičkom građom dijelom je smanjeno (mrežni katalog), a dijelom povećano (KGZ portal, Kalendar godišnjica) u vrijeme zatvaranja knjižnica te ni neposredno nakon ponovnog otvaranja nije doseglo razinu prije zatvaranja.

Posebno je značajno da je i nakon ponovnog otvaranja knjižnica ostao povećani interes korisnika za cjelovite digitalne sadržaje, odnosno za digitaliziranu građu i $e$-knjige, a cjeloviti digitalni sadržaji korišteni su pri izradi novih sadržaja i usluga. To je važan pokazatelj značaja digitalnog segmenta poslovanja i svakako ga treba uvažiti pri određivanju prioriteta u planiranju daljnjeg razvoja Knjižnica grada Zagreba

Iz navedenoga proizlazi zaključak o važnosti ulaganja u kvalitetne mrežne usluge i sadržaje, u nabavu elektroničke građe, u edukaciju djelatnika za vještine i znanja potrebne za rad na daljinu te u opremu koja podržava rad na daljinu i povećan interes korisnika za mrežne usluge i sadržaje.

Cjelovito sagledavanje posljedica tih izvanrednih događaja tek slijedi i neophodno je kako bi se učinkovito djelovalo na daljnji rad i razvoj knjižnica.

\section{LITERATURA}

Bastić, D.; T. Nebesny; A. Simić-Belan. Strateški plan 2014. - 2020.: Knjižnice grada Zagreba. Zagreb, Knjižnice grada Zagreba, 2013.

Bosančić, B. Online referentne usluge: pregled razvoja u teoriji i praksi. // Vjesnik bibliotekara Hrvatske 53, 1(2010), 64-68. [citirano: 2020-12-15]. Dostupno na: https://www.hkdrustvo.hr/vjesnik-bibliotekara-hrvatske/index.php/vbh/article/ view/446/441.

Bosančić, B. Put k povezivanju: usluga Pitajte knjižničare na mrežnim stranicama narodnih knjižnica. // Vjesnik bibliotekara Hrvatske 46, 3/4(2003), 80-92. 
Digitalizirana zagrebačka baština. // Knjižnice grada Zagreba. [citirano: 2021-03-26]. Dostupno na: http://kgzdzb.arhivpro.hr.

Digitalizirana zagrebačka baština: zbirke. // Knjižnice grada Zagreba. [citirano: 202103-26]. Dostupno na: https://digitalnezbirke.kgz.hr.

[Eight hundred] 800 years of shared cultural heritage: Hungary-Croatia. [citirano: 202103-26]. Dostupno na: https://mnm.hu/virtualis/arsetvirtus/.

IFLA/UNESCO Manifest za digitalne knjižnice. // Vjesnik bibliotekara Hrvatske 55, 2(2012) 193-196.

Izvještaj o radu (Knjižnica grada Zagreba). [citirano: 2021-04-13]. Dostupno na: http:// www.kgz.hr/hr/o-nama/godisnji-izvjestaji/43616.

Knežević, S. Zagrebački povijesni trgovi, parkovi i neke ulice. Zagreb: ArTresor, 2020.

Kućne riznice: zbirka fotografija kućnih knjižnica. // Knjižnice grada Zagreba. [citirano: 2021-03-26]. Dostupno na: http://www.kgz.hr/hr/dogadjanja/kucne-riznice-zbirka-fotografija-kucnih-knjiznica/55780.

Ministarstvo kulture. Strateški plan Ministarstva kulture 2020. - 2022. Zagreb: Ministarstvo kulture, 2019. [citirano: 2020-12-15]. Dostupno na: https://min kulture.gov. $\mathrm{hr} /$ UserDocsImages/dokumenti/Strate $\%$ C5\%A1 ki\%20plan $\% 20$ Ministarstva $\% 20$ kulture\%202020.\%20-2022..pdf.

Ministarstvo uprave. Strategija e-Hrvatska 2020. 2017. [citirano 2020-12-15]. Dostupno na: https://rdd.gov.hr/UserDocsImages//MURH_migracija\%20s\%20weba// Strategija_e-Hrvatska_2020.pdf.

Nacionalni plan digitalizacije kulturne baštine 2025. [citirano 2020-12-15]. Dostupno na: https://esavjetovanja.gov.hr/ECon/MainScreen?entityId=10350.

Nagovnak, K. Informationsressourcen für Slawisten. Berlin: De Gruyter Saur, 2017.

Strategija kulturnog i kreativnog razvitka Grada Zagreba 2015. - 2022. Zagreb, 2015. [citirano 2020-12-15]. Dostupno na: https://www.zagreb.hr/userdocsimages/arhiva/04\%20Strategija.pdf.

Škrabo, K.; R. Vrana. Digitalne zbirke u narodnim knjižnicama u Hrvatskoj. // Vjesnik bibliotekara Hrvatske 60, 1(2017), 103-136. DOI: https://doi.org/10.30754/ vbh.60.1.539.

Zbirka Zagrabiensia. // Knjižnice grada Zagreba. [citirano: 2021-03-26]. Dostupno na: http://www.kgz.hr/hr/knjiznice/gradska-knjiznica-zbirka-zagrabiensia/male-izlozbe/prvostolna-crkva-zagrebacka-poslije-potresa-9-studenoga-1880-22-ozujka-2020/55651. 